\title{
Assessment of thermal and energy performance of masonry blocks prepared with date palm ash
}

\author{
Noman Ashraf ${ }^{1}$ [D $\cdot$ Muhammad Nasir $^{2} \cdot$ Walid Al-Kutti ${ }^{2} \cdot$ Faris A. Al-Maziad $^{1}$
}

Received: 11 November 2019 / Accepted: 22 July 2020 / Published online: 12 August 2020

(c) The Author(s) 2020

\begin{abstract}
This article evaluates the thermal and energy performance of mortar blocks containing local agricultural waste. The mortar blocks were cast by the replacement of ordinary Portland cement (OPC) with varying amounts of date palm ash (DPA) in the range of 10-30\%. Experiments and simulations were carried out to assess the thermal characteristics and energy performance of the specimens. A prototype office building was modeled and simulated in DesignBuilder (Version 6.1.06) with modified blocks prepared with DPA under the Arabian Gulf environment characterized by hot and humid climatic conditions of Dhahran, Saudi Arabia. The developed blocks are characterized as lightweight blocks based on density data which satisfy the requirement of ASTM C55-11. The analysis and simulation indicate that the incorporation of DPA improves the thermal resistance of up to $47 \%$, enhances the indoor environment and yields annual energy consumption of up to $7.6 \%$, consequently reduces the cost of masonry block production by $\sim 11 \%$ without compromising the physical, chemical, and mechanical properties. The masonry blocks prepared with DPA found to be economical than conventional masonry blocks. It is postulated that the novel DPA-based developed blocks are significantly sustainable products which will contribute to the valorization of DPA waste along with the reduction in the cost of construction and operational cost of the building.
\end{abstract}

Keywords Date palm ash $\cdot$ Thermal characteristics $\cdot$ Energy simulation $\cdot$ DesignBuilder $\cdot$ Blocks

\section{Introduction}

The world energy consumption and associated $\mathrm{CO}_{2}$ emission are increasing at an unprecedented rate due to population growth and globalization effects. The contribution from the building's structure to global energy consumption has gradually increased which accounts for almost $1 / 3^{\text {rd }}$ of the greenhouse gas emissions [1]. This is because buildings represent a significant percentage of the world's energy consumption and associated $\mathrm{CO}_{2}$ emissions [2]. For instance, in the US. and Europe, the energy consumption due to the building sector represents $39-40 \%$ while $36-38 \%$ is due to $\mathrm{CO}_{2}$ emissions [3]. In the case of the Kingdom of Saudi

Noman Ashraf

nasheaf@iau.edu.sa; replyashraf@gmail.com

1 Department of Building Engineering, College of Architecture and Planning, Imam Abdulrahman Bin Faisal University, Dammam 31451, Saudi Arabia

2 Department of Civil and Construction Engineering, College of Engineering, Imam Abdulrahman Bin Faisal University, Dammam 31451, Saudi Arabia
Arabia (KSA), the energy consumption due to the buildings is about $70 \%$ of the total electrical energy consumption of the country [4-6]. Due to urbanization and population rise, the demand in infrastructure is rising, which leads to the higher consumption of building material, particularly ordinary Portland cement (OPC) [7]. The major drawback of manufacturing ordinary Portland cement is its energyintensive process which contributes to high emissions of $\mathrm{CO}_{2}$ into the atmosphere. Previous studies indicate that $2 \%$ of the world's energy and 5\% of the world's industrial energy are consumed by the cement industry sector, which accounts for emitting $5 \%$ of $\mathrm{CO}_{2}$ emissions and it is one of the largest sources of anthropogenic emissions of $\mathrm{CO}_{2}$ [8]. This prompted the development of green construction products using alternative materials. Numerous studies have explored the possibility of utilizing solid wastes and found them superior for construction [9-12]. Such agro-industrial wastes-based researches incorporated wood waste ash [13], natural pozzolan [14], fly ash [15], rice husk ash [16], date palm ash (DPA) [17], palm oil fuel ash [11], metakaolin [18], silica fume [19], ground granulated blast furnace slag [20], and superpozz [21] exhibited excellent performances. 
In the recent past, there has been growing interest in the utilization of by-products that are disposed of as solid stockpiles and landfills, to recycle them as supplementary cementitious materials (SCMs) due to their economic, environmental and technical merits. Several studies reported the potential and optimum dosage of SCMs to be partially mixed with OPC, and its effects on mix design, exposure conditions, and performance with concrete [15, 17, 22-24].

Khalil and Algamal [7] examined the Partial Replacement of Ordinary Portland Cement with local natural Minerals from Jeddah regions of KSA. The authors found the specimens' mechanical and economical aspects were improved significantly. Zeyad et al. [25] investigated concrete mixtures prepared with two sets of volcanic pumice powder (VPP) and polypropylene fiber. They conducted the lab test and found tensile and flexural strengths were optimized at 10\% VPP. Kannan et al. [26] examined the High-performance concrete (HPC) mixtures incorporating 10-40\% Ceramic waste powder (CWP) as replacement of Portland cement, and found that the specimen exhibits high strength and excellent durability while microstructure investigations showed that there was no significant difference in cement hydration compared to the cement without CWP. Singh et al. [27] investigated the effect of partial replacement of cement by waste marble slurry in Rajasthan, India. The authors performed the laboratory test and found the mechanical properties of concrete enhanced with the incorporation of dried marble slurry up to $15 \%$ replacement. Ismail et al. [11] performed the laboratory test on the bricks fabricated from paper sludge and palm oil fuel ash (POFA). They found that the brick made with $60 \%$ cement, 20\% sludge and 20\% POFA satisfies the standard for precast concrete masonry units.

Kupwade-Patil et al. [28] studied the effect on Embodied Energy Coefficients (EEC) when Ordinary Portland Cement (OPC) was partially substituted by natural Pozzolanic Volcanic Ash (VA). They found that the replacement of OPC with volcanic ash decreases by about $16 \%$ in EEC. Blaisi [29] experimentally conducted the environmental assessment of utilizing date palm ash as partial replacement of cement in mortar and found that the DPA poses no environmental risk to human health when used as a cement replacement. A study [30] of the utilization of date palm fibers (DPF) with cement and sand has found that 5\%,10\%, and $15 \%$ of DPF loading in the mortar yield good thermal and mechanical properties of the composite which could be used as the energy efficient building components.

The literature review reveals that a substantial amount of research has been carried out, and researchers are still underway, to exploit the benefit of replacing the OPC with solid waste in improvising the thermal, environmental, physical, microstructural aspects of the composites. Recently, AlKutti and co-workers [17, 22, 23] experimentally evaluated the mortar specimen prepared by the partial replacement of
OPC with DPA in the proportion of $10-30 \%$ and found that mechanical, durability and microstructural performance of the specimens were enhanced. Moreover, mechanical and durability property values satisfy the relevant international standards with the DPA dosage up to $30 \%$, whereas the optimum value was obtained for the mortar specimen with $10 \%$ DPA. However, the thermal and energy performance of the novel DPA blocks have not been explored. Accordingly, the current focus of the study is to examine the impact of DPA loading on thermal characteristics, energy consumption, and indoor environment of the building. The findings promote application of DPA in block making to valorize generation of date palm waste, minimize the cost of construction as well as operational cost of the building, and maximize the sustainable practice in the construction industry.

\section{Materials and methods}

\section{Materials}

Ordinary Portland cement (OPC) - Type I in compliance with ASTM C150 was used in each mixture. DPA was procured from the date farm at Al-Hasa city located in the Eastern region of Saudi Arabia. DPA was produced as an aftermath of burning waste date tree fronds that is continuously supplied as a fuel material during the production of charcoal from the firewood. The stages of DPA generation are depicted in the form of a flow chart in Fig. 1 [31].

\section{Specimen preparation}

The mortar cubical specimens of $50 \times 50 \times 50 \mathrm{~mm}$ size were prepared using $100 \%$ OPC (control mix) and the partial replacement of OPC by DPA with the varying dosage as summarized in Table 1. The samples were designated as $\mathrm{OPC}_{x}-\mathrm{DPA}_{y}$ where $x$ and $y$ represent the percentage of OPC and DPA, respectively. For example, $\mathrm{OPC}_{90}-\mathrm{DPA}_{10}$ means cementitious material consists of $90 \%$ OPC while DPA is $10 \%$. The density of the cementitious material was $350 \mathrm{~kg} / \mathrm{m}^{3}$, water to the cementitious material ratio $(\mathrm{w} / \mathrm{cm})$ was maintained 0.4 while cementitious material to sand ratio was kept 1:2.10 in all mixtures.

\section{Experimental investigation of thermal characteristics and density}

The equivalent thermal conductivity $(k)$ and specific heat capacity $\left(C_{\mathrm{p}}\right)$ test of the control and DPA-based mortar were performed by the transient hot bridge (THB) method with the analyzer Linseis THB-100, Germany.

The Transient Hot Bridge is based on a non-steady state or time depended measuring method. The advantage of this 


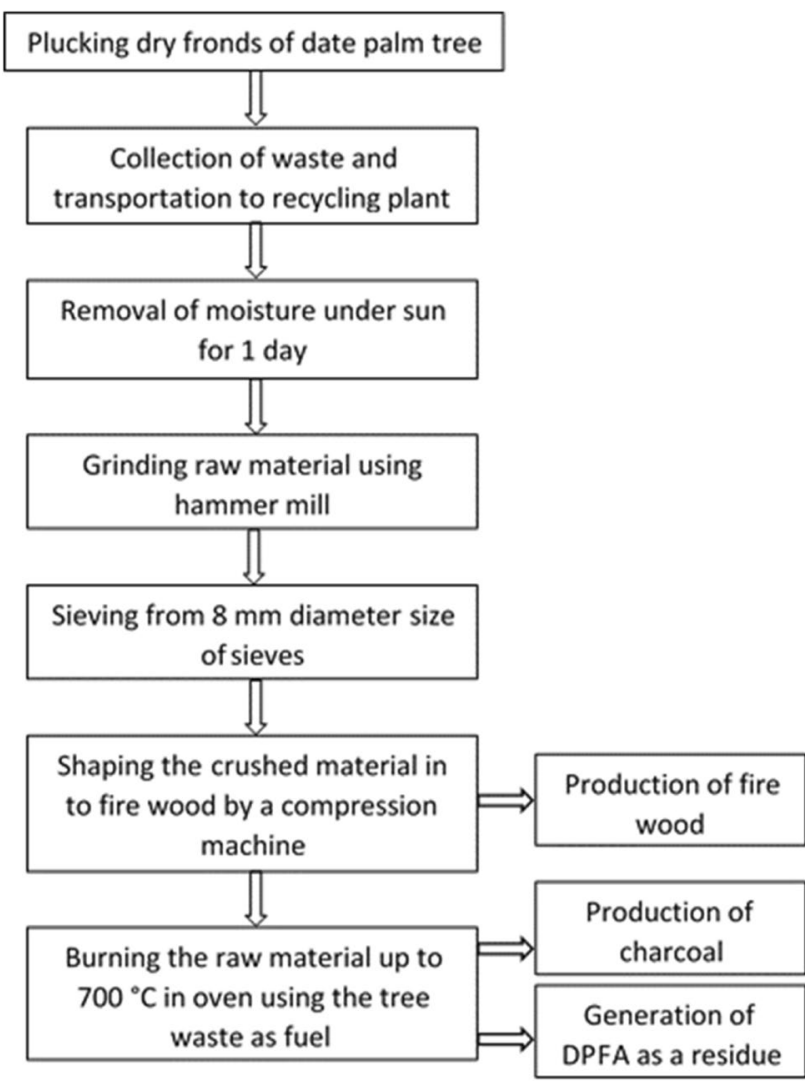

Fig. 1 DPA generation process

Table 1 Mixture proportion

\begin{tabular}{lr}
\hline Sample type & \multicolumn{1}{l}{ Ratio } \\
\hline Type 1 $\left(\mathrm{OPC}_{100}-\mathrm{DPA}_{0}\right)$ & OPC: Sand $=1: 2.10($ Control $)$ \\
Type 2 $\left(\mathrm{OPC}_{90}-\mathrm{DPA}_{10}\right)$ & OPC + DPA $(10 \%):$ Sand $=1: 2.10$ \\
Type 3($\left(\mathrm{OPC}_{80}-\mathrm{DPA}_{20}\right)$ & OPC + DPA $(20 \%):$ Sand $=1: 2.10$ \\
Type 4(OPC & OPC + DPA $(30 \%):$ Sand $=1: 2.10$ \\
\hline
\end{tabular}

method compared to the steady-state model is shorter measuring time, and it can measure thermal diffusivity in parallel to the thermal conductivity. The measurements comply with ASTM D7984 and ISO 22007-2 standards. The electrical current of $75 \mathrm{~mA}$ was applied to the strip-shaped sensor, model THB6K77, which was used as heater and temperature sensor, embedded between the identical samples of thickness $50 \mathrm{~mm}$, measurement time ranged between 60-100 s [33]. The pictorial and schematic view of the test set-up is illustrated in Fig. 2a and b. The strip emits a constant heat flow during the measurement, causes a rise in temperature. The temperature rise over time corresponds to the thermal transport properties of the sample. The properties such as thermal conductivity, thermal diffusivity, and the specific heat capacity were evaluated by solving complex thermal conductivity equations through a known power input and temperate raise [34]. It was ensured that the Linseis THB100 was calibrated before each measurement with materials of known thermal conductivity polymethyl methacrylate (PMMA). Multiple measurements were performed for each sample and their average values were recorded.

\section{Building description and Simulation}

To assess the thermal effectiveness of mortar blocks comprising OPC and DPA, energy simulations were performed on a typical office building located at Dhahran, KSA. The specification of the studied building is summarized in Table 2. The data such as Lighting power density (LPD), Equipment power density (EPD), Occupancy, and set point temperature complied with ASHRAE standard [35, 36]. The thermal characteristics and density value obtained experimentally (Table 3) were used in the simulation program to estimate the energy performance of masonry block specimens (Table1), used as a structural component in the external wall. Figure 3 illustrates the external wall structure used
Fig. 2 Test set-up for thermal conductivity test. a Pictorial view, b schematic view

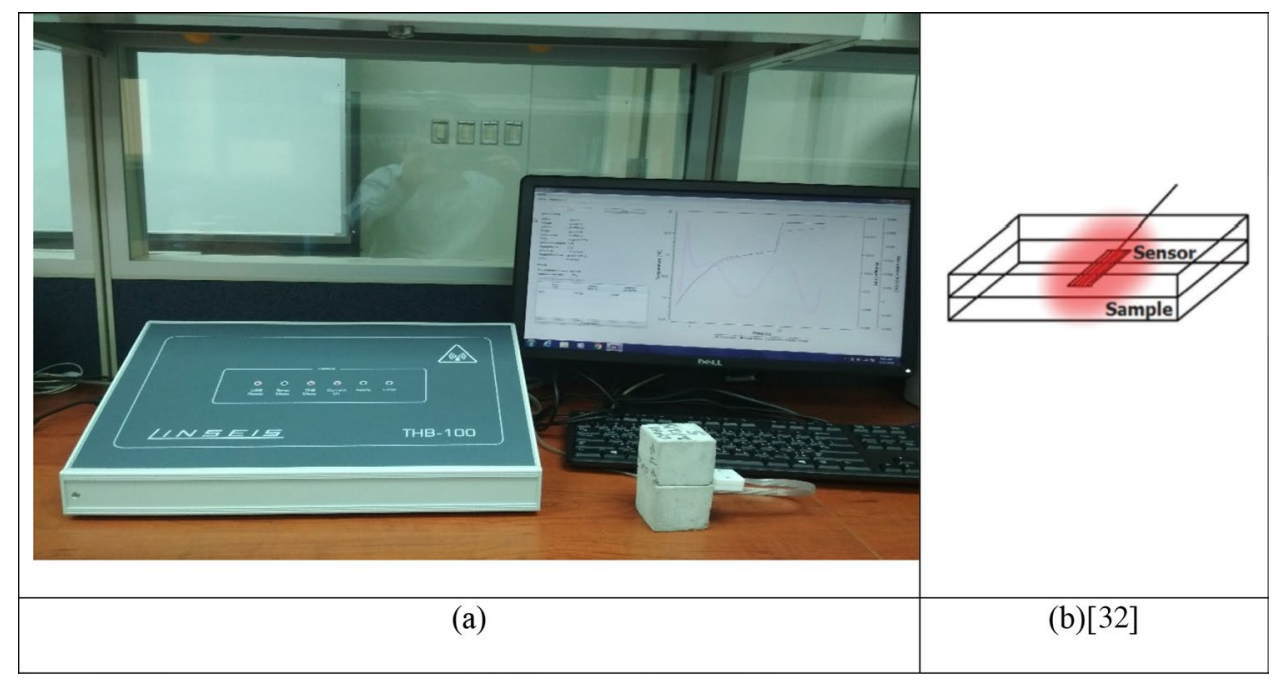


Table 2 Building specification for simulation program

\begin{tabular}{ll}
\hline $\begin{array}{l}\text { Type of building } \\
\text { Location }\end{array}$ & $\begin{array}{l}\text { Office } \\
\text { Dhahran, Kingdom of Saudi } \\
\text { Arabia }\end{array}$ \\
Gross Area & $560 \mathrm{~m}^{2}$ \\
No. of floors & 3 \\
Orientation & North-South \\
External Wall & $200 \mathrm{~mm}$ concrete masonry units \\
& $(\mathrm{CMU})$ block-15 mm of plas- \\
& ter inside and outside \\
Roof & $200 \mathrm{~mm}$ concrete, slab $50 \mathrm{~mm}$ \\
& screed, 50 mm sand and \\
Glazing & $10 \mathrm{~mm}$ ceramic tiles \\
Window to wall ratio (WWR) & $6 \mathrm{~mm} \mathrm{double} \mathrm{reflective} \mathrm{glass}$ \\
Floor height & $1: 10$ \\
Window glass & $4 \mathrm{~m}$ \\
Longitude & Double Glazing \\
Latitude & $50.17^{\circ} \mathrm{E}$ \\
Altitude & $26.27^{\circ} \mathrm{N}$ \\
HVAC system & $17 \mathrm{~m}$ \\
Set point temperature & Central \\
Occupancy & $20-24^{\circ} \mathrm{C}$ \\
Lighting power density (LPD) & $0.08 \mathrm{person} / \mathrm{m}^{2}$ \\
Equipment power density (EPD) & $8 \mathrm{~W} / \mathrm{m}^{2}$ \\
\hline &
\end{tabular}

in the current study which is the local practice and in compliance with the Saudi Arabian standard [37, 38]. The studied building was modeled and simulated in DesignBuilder (Version 6.1.06). DesignBuilder is the interface of Energy Plus simulation engine, uses dynamic parameters to produce detail environmental performance data. The calculations are based on heat balance technique considering the simultaneous interaction of building models with outdoor weather conditions to evaluate the various loads on an hourly basis. The physical characteristics of the building model are summarized in Table 2. Figure 4 illustrates the climatic profile of Dhahran. It is evident from the figure that hot climate prevails over almost 10 months of the year, representing a typical cooling-dominated climate. Figure 5 illustrates the annual sun path with hourly solar angles over the base-case building model. The rationale of modeling Dhahran city is justified because its climate is categorized as an extremely hot and humid climate [39].

\section{Validation and calibration of simulation program}

The validation and calibration of simulation results were done by monthly electricity consumption billing records of an existing office building in Dhahran, KSA. The building was modeled in the simulation program and all the parameter such as occupancy, lighting power density (LPD), equipment power density (EPD), HVAC system, were inputted, which are recorded from the existing office building and are also in compliance with ASHRAE standard [36]. Figure 6 shows the monthly electrical energy consumption for the building base-case model predicted by the DesignBuilder and the actual energy billing for the year 2017. It is worth noting that there is less than $2 \%$ difference in result between the simulation program and the utility bill data which is lower than that reported by Iqbal and Al-Hamoud [4], who studied the energy conversion measures for an office building, in the same region of KSA, and therefore could be considered reasonably acceptable.

\section{Results and discussion}

Thermal conductivity results of the specimens were first presented to understand the effect of DPA dosage on thermal characteristics followed by estimating the annual energy consumption. Then effect of DPA on unit cost of the specimens was reported.

\section{Thermal characteristic and density}

The thermal conductivity, specific heat capacity, and density values were evaluated experimentally for various developed blocks are summarized in Table 3. For determining the thermal characteristic, transient hot bridge method was used. Obtained thermal conductivity of the developed blocks and

Table 3 Thermal conductivity, specific heat capacity and density of masonary block sample

\begin{tabular}{|c|c|c|c|c|c|}
\hline Sample type & Description & $\begin{array}{l}\text { Equivalent thermal con- } \\
\text { ductivity }(\mathrm{W} / \mathrm{mK})\end{array}$ & $\begin{array}{l}\text { Specific heat capac- } \\
\text { ity }(\mathrm{J} / \mathrm{Kg} \mathrm{K})\end{array}$ & Density $\left(\mathrm{kg} / \mathrm{m}^{3}\right)$ & $\begin{array}{l}\text { Thermal resist- } \\
\text { ance }\left(\mathrm{m}^{2} \mathrm{~K} / \mathrm{W}\right)\end{array}$ \\
\hline Type 1 (Base Case) & $\begin{array}{l}\mathrm{OPC}_{100^{-}} \\
\mathrm{DPA}_{0 \text { (Normal mortar block) }}\end{array}$ & 0.81 & 2250 & 840 & 0.456 \\
\hline Type 2 & $\mathrm{OPC}_{90}-\mathrm{DPA}_{10}$ & 0.693 & 2184 & 810 & 0.5 \\
\hline Type 3 & $\mathrm{OPC}_{80}-\mathrm{DPA}_{20}$ & 0.537 & 2088 & 796 & 0.584 \\
\hline Type 4 & $\mathrm{OPC}_{70}-\mathrm{DPA}_{30}$ & 0.434 & 2032 & 780 & 0.672 \\
\hline
\end{tabular}




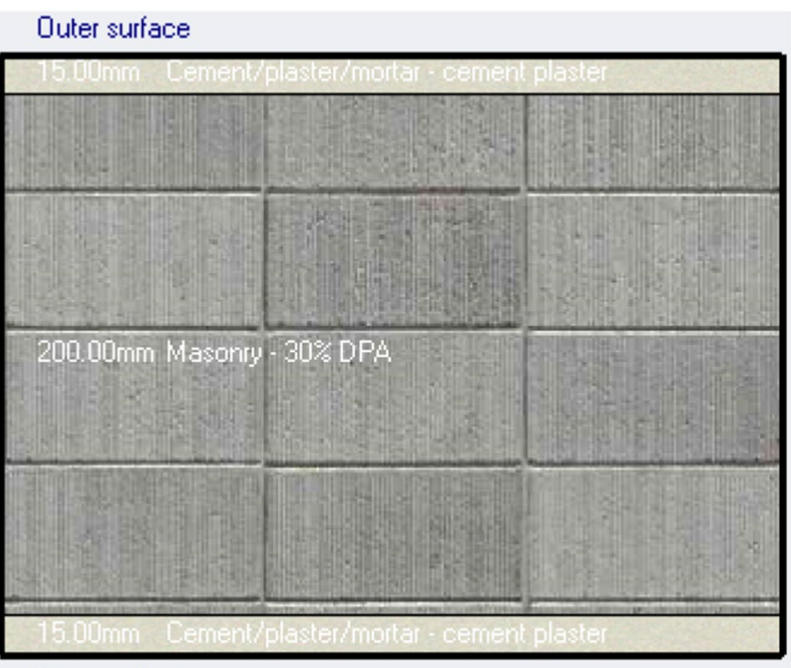

Inner surface

Fig. 3 Schematic of wall configuration

the control block is given in Table 3, the control specimen properties are similar to the commercially available masonry block. The observed thermal conductivity values vary in between a minimum of $0.432 \mathrm{~W} / \mathrm{mK}$ for the specimen with $30 \%$ DPA (Type 4), and a maximum of $0.81 \mathrm{~W} / \mathrm{mK}$ for the control specimen (Type 1). This result is in close agreement with that of Al-Dharmi and Iqbal [40] who studied the thermal performance of different types of masonry blocks used in Saudi Arabia and found that the thermal conductivity of the masonry block was $0.83 \mathrm{~W} / \mathrm{mK}$. The thermal performance of block follows a similar pattern as that of density which points out to the fact that the proportion DPA content is significant in lowering heat transfer rate through the material. The porosity of the DPA-based block is higher than the control block, as reported in the author's previous study [24], thus affecting the overall thermal conductivity of the material. The thermal conductivities of specimens with $10 \%$ DPA (Type 2) and 20\% DPA (Type 3) are $0.693 \mathrm{~W} / \mathrm{mK}$ and $0.573 \mathrm{~W} / \mathrm{mK}$, respectively. It is worth noting that the reduction in thermal conductivity of the specimen with $30 \%$ DPA (Type 4) compared to the control specimen (Type 1) is $46.67 \%$. These findings are in good agreement with the previous study [41] on thermal conductivity of mortars containing polyurethane waste particles, which reported a maximum of $20 \%$ decrement in thermal conductivity could be achieved by the mortar mixture containing $30 \%$ polyurethane. The decrement in thermal conductivity has also been reported by Milani and Labaki [42], who analyzed the masonry block prepared by the partial replacement of cement with rice husk ash and compared with the normal masonry block.

The thermal resistance ( $R$-value) of the commercially available mortar block (Type 1) and the blocks prepared
Fig. 4 Climate profile of Dhahran, Saudi Arabia [Courtesy: climatemps.com]

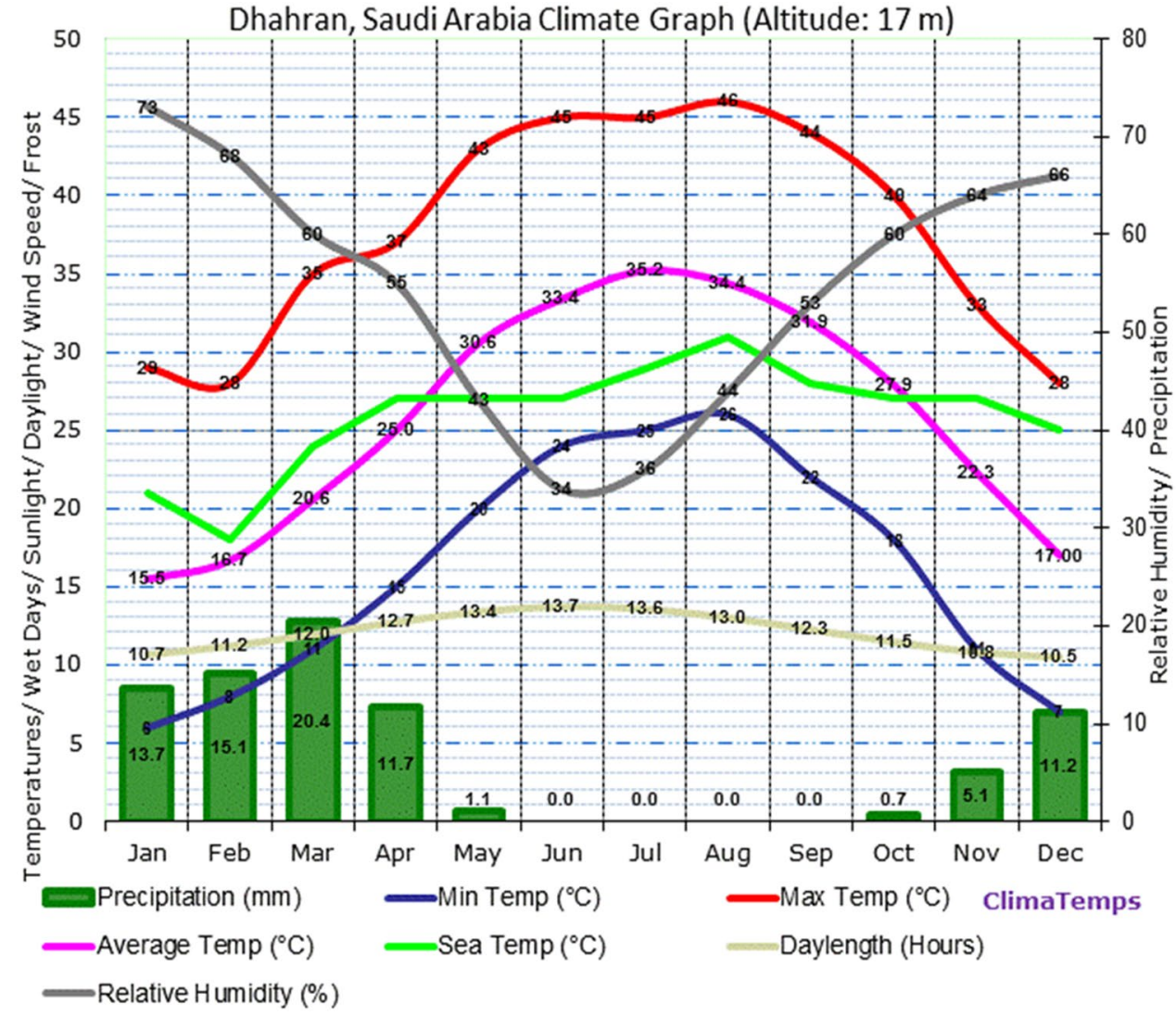

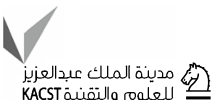
Springer 
Fig. 5 Annual sun path over Building model

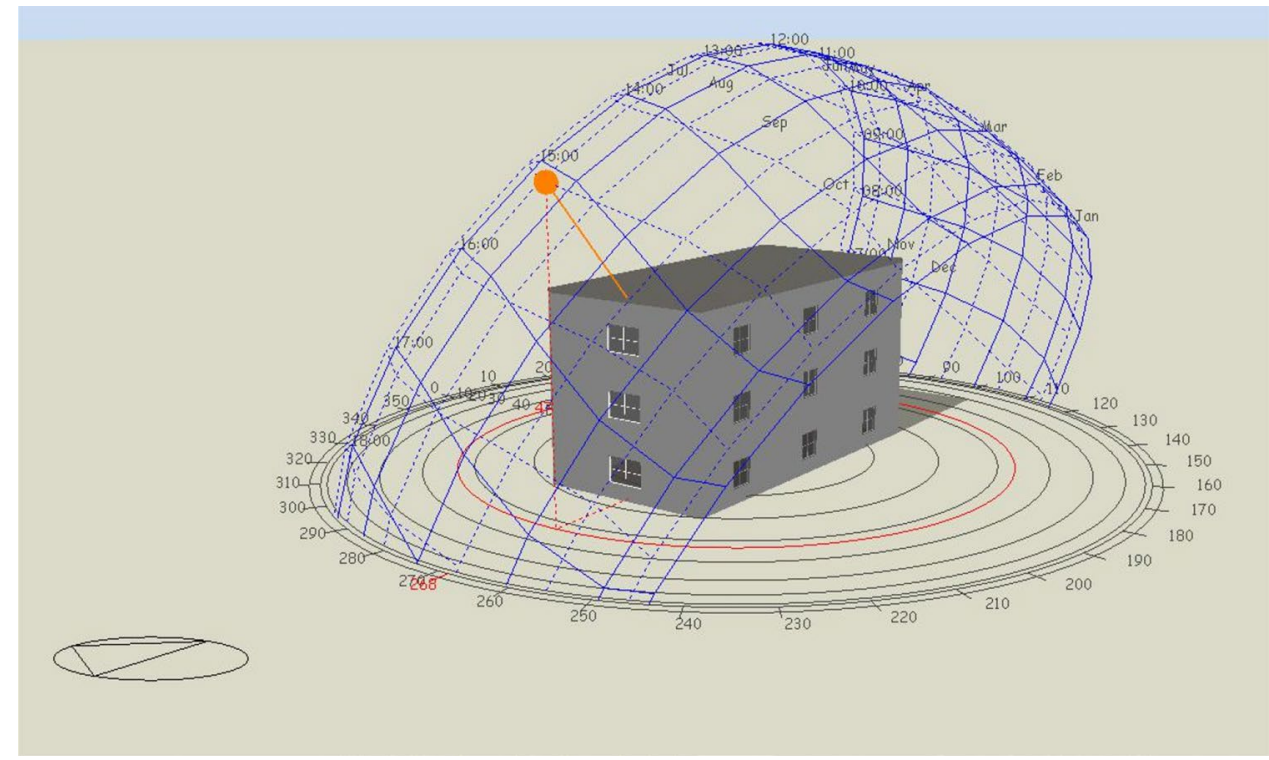

25000

- Base Case $\quad$ Year 2017

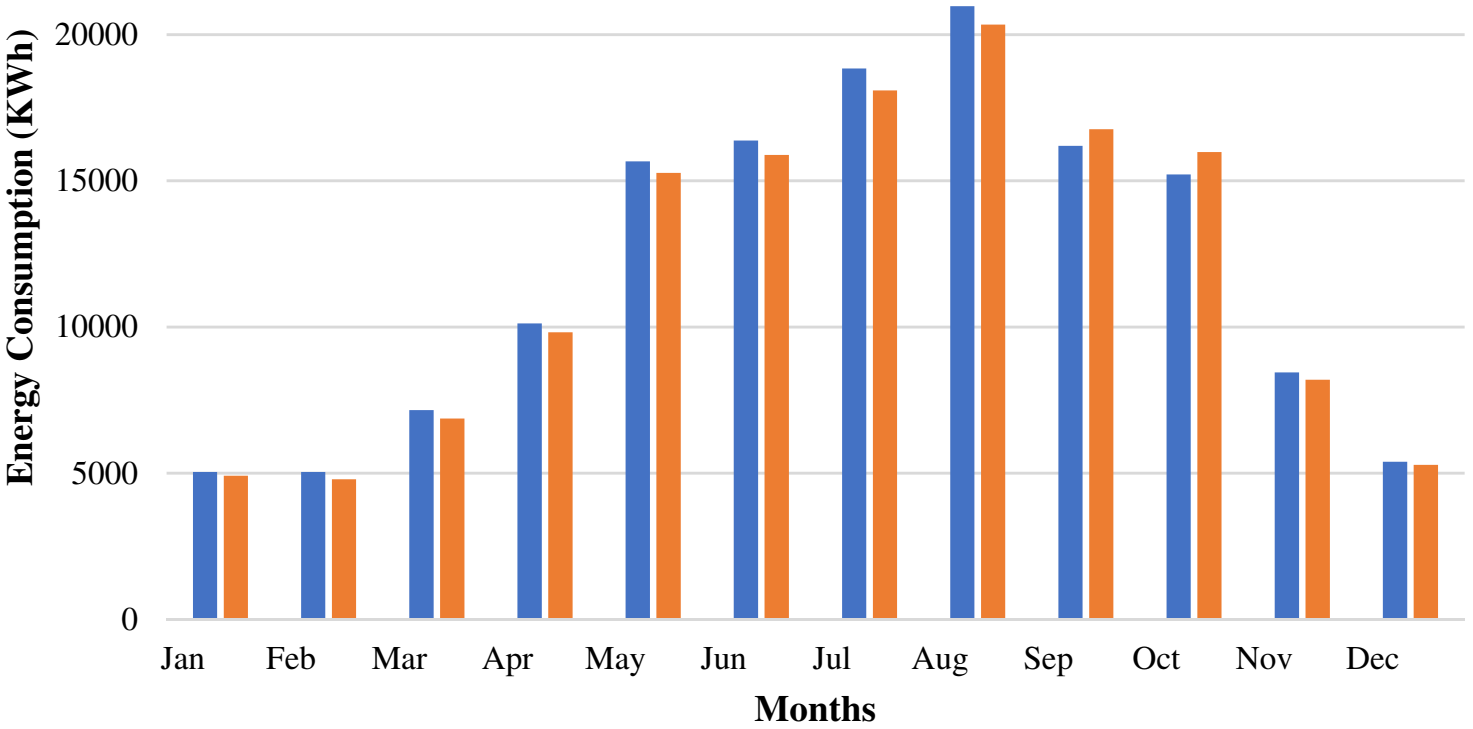

Fig. 6 Comparison of monthly energy consumption predicted from simulation program and actual electrical consumption (2017)

with DPA are compared in Fig. 7, while the percentage increase in thermal resistance by the addition of DPA is shown in Fig. 8. It can be observed that Type 4 specimen has $47.4 \%$ higher thermal resistance compared to control specimen (Type 1), followed by Type 3 (28\%) and Type $2(9.6 \%)$ in decreasing order of efficiency. This trend correlates with thermal conductivity data of the present study and also reported elsewhere [40, 43-53]. It is worth mentioning that the density of the blocks decreases with increase in the DPA content such that the reduction of
$3.57 \%, 5.24 \%$ and $7.14 \%$ corresponding to type 2,3 and 4 block are respectively recorded (Table 3 ), owing to the less bulk density of DPA particles. The density values fall in the range of $650-1500 \mathrm{~kg} / \mathrm{m}^{3}$, which follows the ASTM C55-11 standard [54] for light weight masonry block. Thus, the decrease in density of the block with the addition of DPA is advantageous in producing lighter masonry blocks which consequently contribute to the reduction in self-weight of the building structure. 
Fig. 7 Comparison of thermal conductivity among different types of blocks

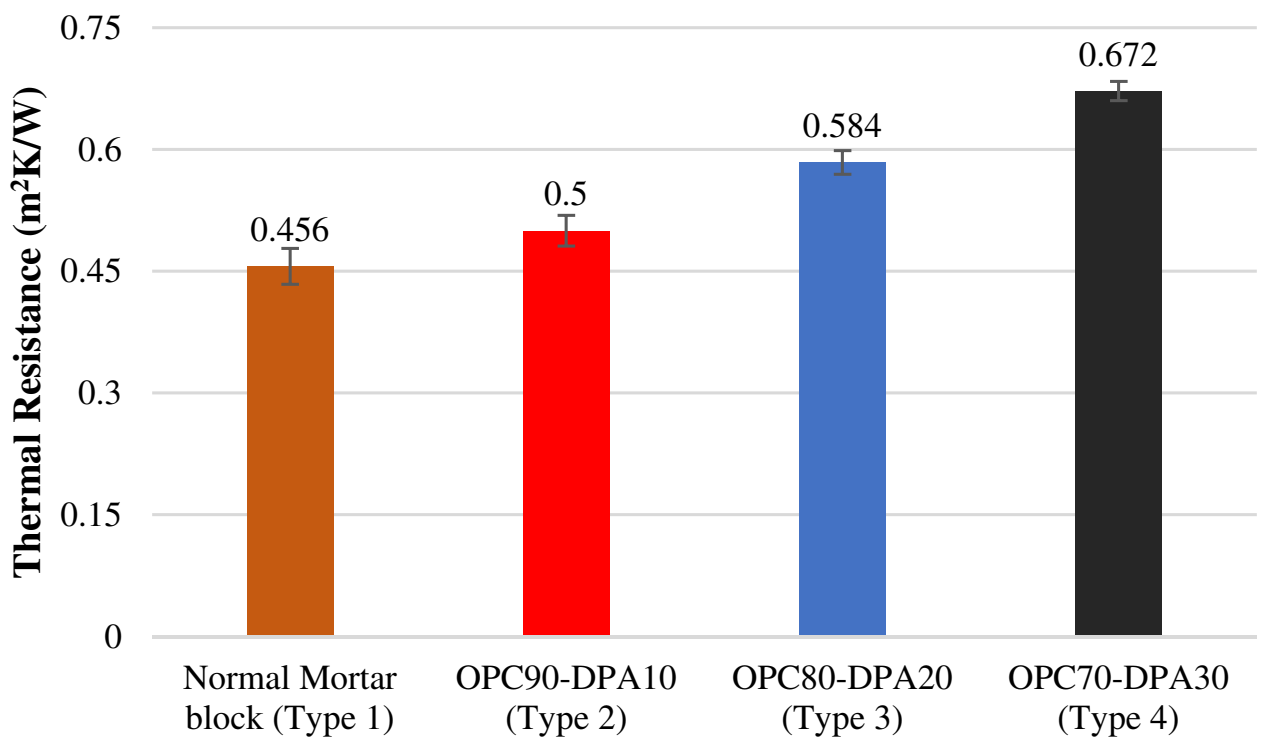

Types of block

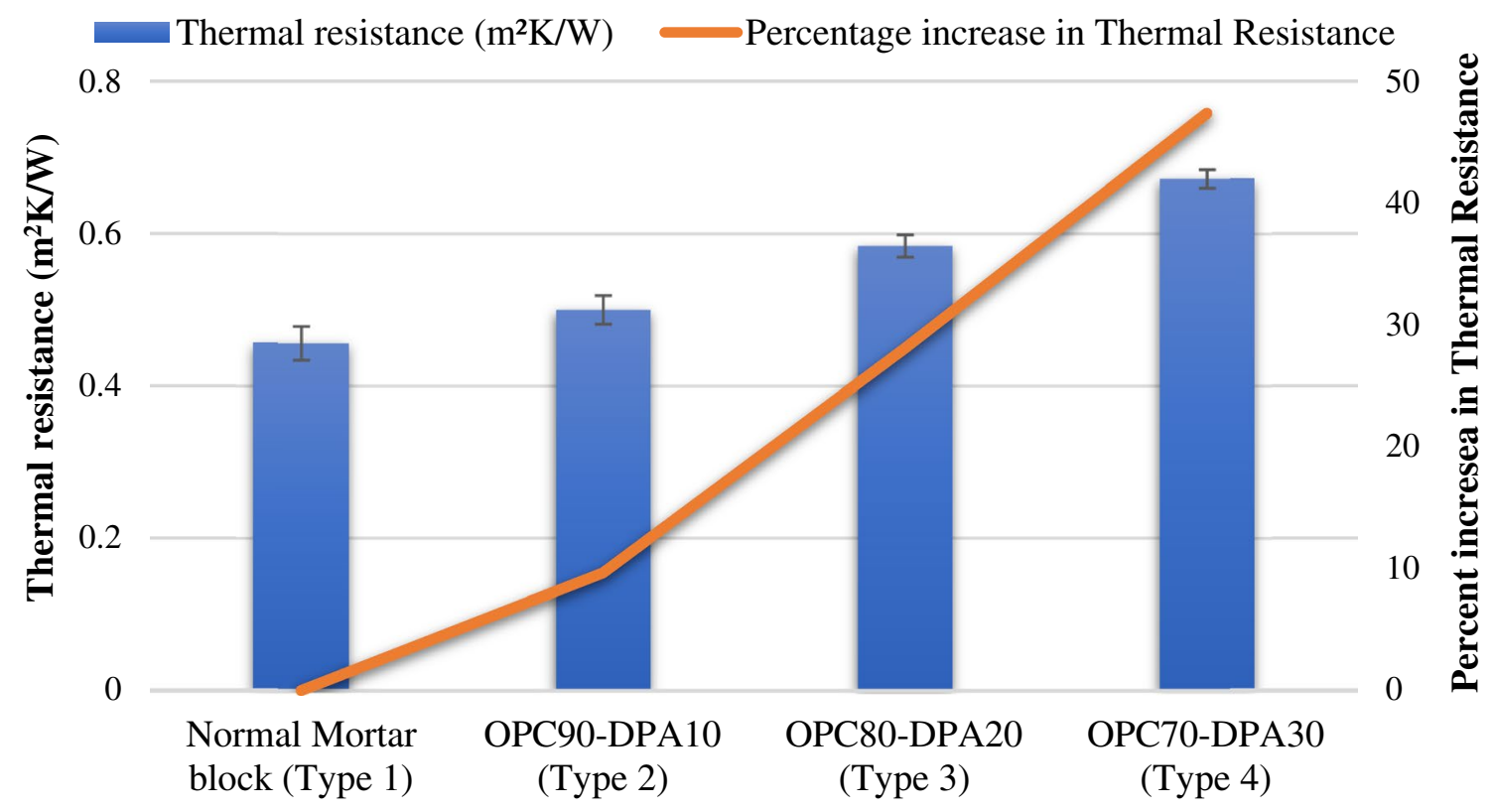

Types of block

Fig. 8 Thermal resistance and Percentage variation among different types of blocks 


\section{Monthly cooling/heating loads and total energy consumption}

\section{Annual Energy consumption}

The density and thermal characteristics of the block specimens estimated through experimentation were used as the input data in the simulation. To explore the energy performance, masonry blocks are used as a structural component of the wall profile as summarized in Table 4, the wall configuration is commonly used in KSA [38].

To assess the impact of DPA block on the energy performance of the building, the annual energy and cooling energy consumption by various wall options were estimated, as plotted in Fig. 9. With respect to the control specimen (Wall 1), the energy-saving potential of the various wall options were also determined (as a percentage of base case) as shown in Fig. 10. It is evident that wall 2 and 3 produced the saving of $6.3 \%$ and $7 \%$ respectively, although the DPA content in the block was increased from 10 to $20 \%$. This is due to the fact that heat gain through the wall is lower compare to the other building structural components [55]. It is observed from Fig. 11 that the Energy Use Index (EUI) and cooling load intensity are reduced to $238.6 \mathrm{kWh} / \mathrm{m}^{2} /$ year and $155.3 \mathrm{kWh} / \mathrm{m}^{2} /$ year respectively, by replacing wall $1(0 \%$
DPA) with Wall 4 (30\% DPA). This is attributed to the fact that density, specific heat, and thermal conductivity of the structural elements play a crucial role in the heat gain of the building [4, 56-58]. Moreover, increment in the thermal resistance reduces the cooling load and vice versa.

It has been found that the cooling load is $65 \%$ of the total energy consumption of the building, which is mainly the combination of internal loads (lighting, occupancy, equipment) and heat transfer through the building fabric. This observation is consistent with research conducted by AlUgla et al. [59]. The energy-saving potential of Wall 2 is observed to be $9.4 \%$, which has been increased to $10.5 \%$ (Wall 3) and $11.3 \%$ (Wall 4), with an addition of $10 \%$ and $20 \%$ of DPA content respectively.

\section{Indoor air temperature}

Impact of wall type on the indoor air temperature of the building was estimated, as plotted in Fig. 12. The data in the figure indicates the maximum indoor temperature is in the month of August, as the outdoor dry bulb temperature is highest during that period (Fig. 4). The results are consistent with those observed in the monthly variation of the cooling load in Fig. 13. In general, it can be observed that the cooling load starts escalating from March, reaches to peak in August, declines and reaches a minimum during
Table 4 Structure of investigated wall
Fig. 9 Annual energy consumption and cooling load for various wall options

\begin{tabular}{llll}
\hline Wall type & Layer (outer) & Layer (intermediate) & Layer (inner) \\
\hline Wall 1 (Base case) & Plaster $(15 \mathrm{~mm})$ & $\begin{array}{c}\text { Masonry block (Type 1) (Con- } \\
\text { trol specimen) }\end{array}$ & Plaster (15 mm) \\
Wall 2 & Plaster $(15 \mathrm{~mm})$ & $\mathrm{OPC}_{90}-\mathrm{DPA}_{10}$ (Type 2) & Plaster (15 mm) \\
Wall 3 & Plaster $(15 \mathrm{~mm})$ & $\mathrm{OPC}_{80}-\mathrm{DPA}_{20}$ (Type 3) & Plaster (15 mm) \\
Wall 4 & Plaster $(15 \mathrm{~mm})$ & $\mathrm{OPC}_{70}-\mathrm{DPA}_{30}$ (Type 4) & Plaster (15 mm) \\
\hline
\end{tabular}

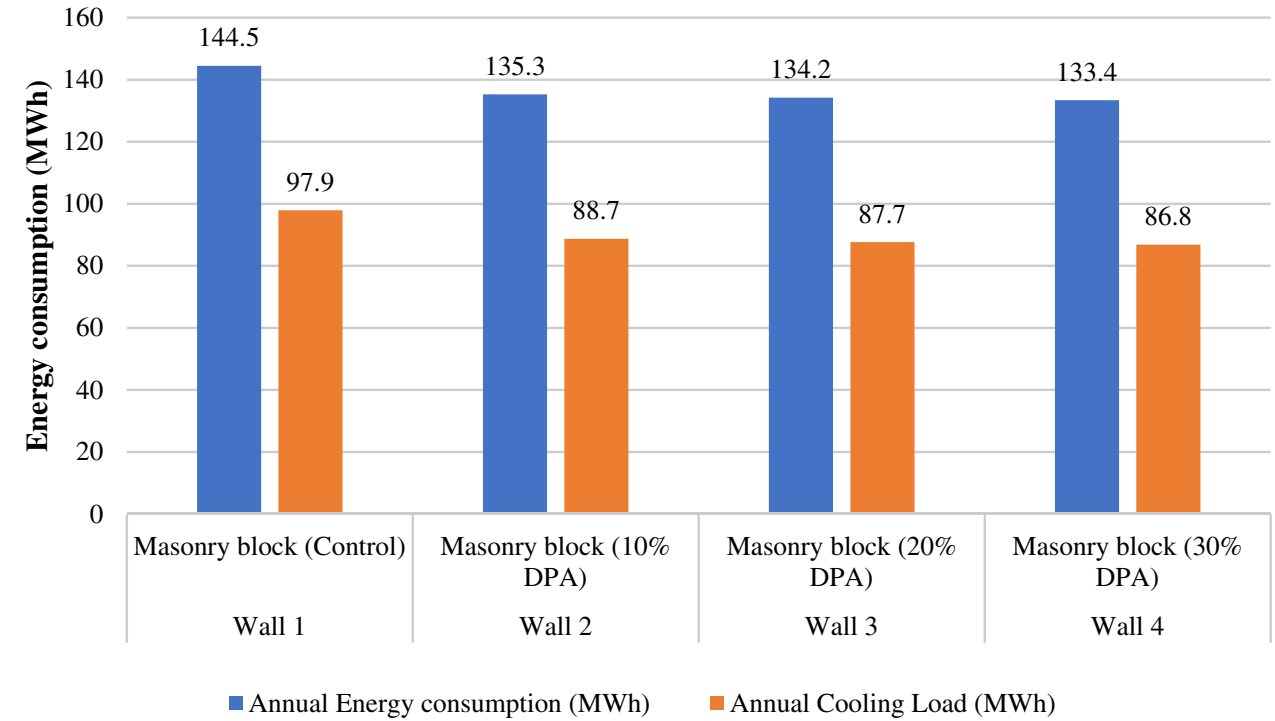


Fig. 10 Energy-saving potential of various wall options compare to base case (control specimen)

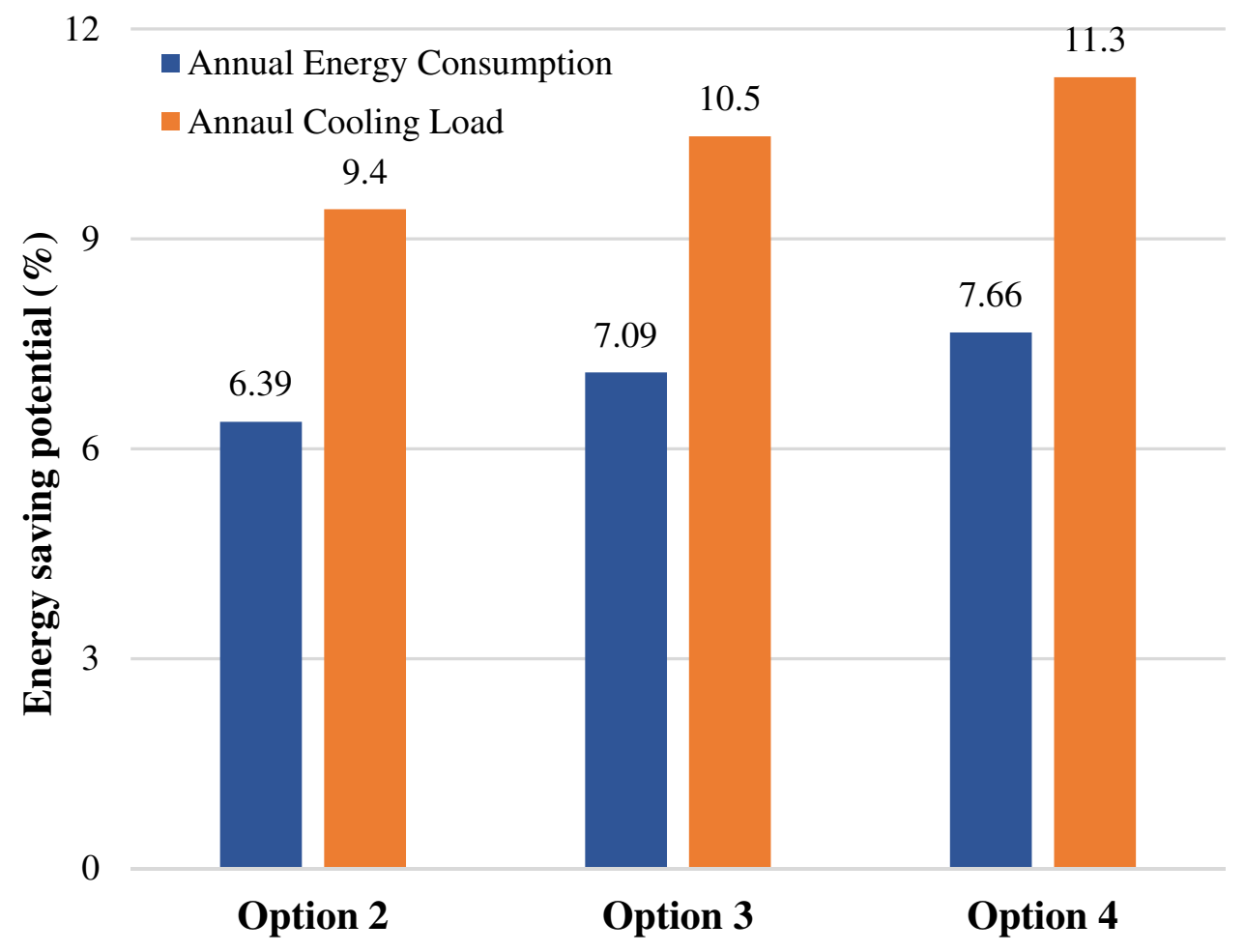

Fig. 11 Cooling Load Intensity and Energy Use Index for various wall options

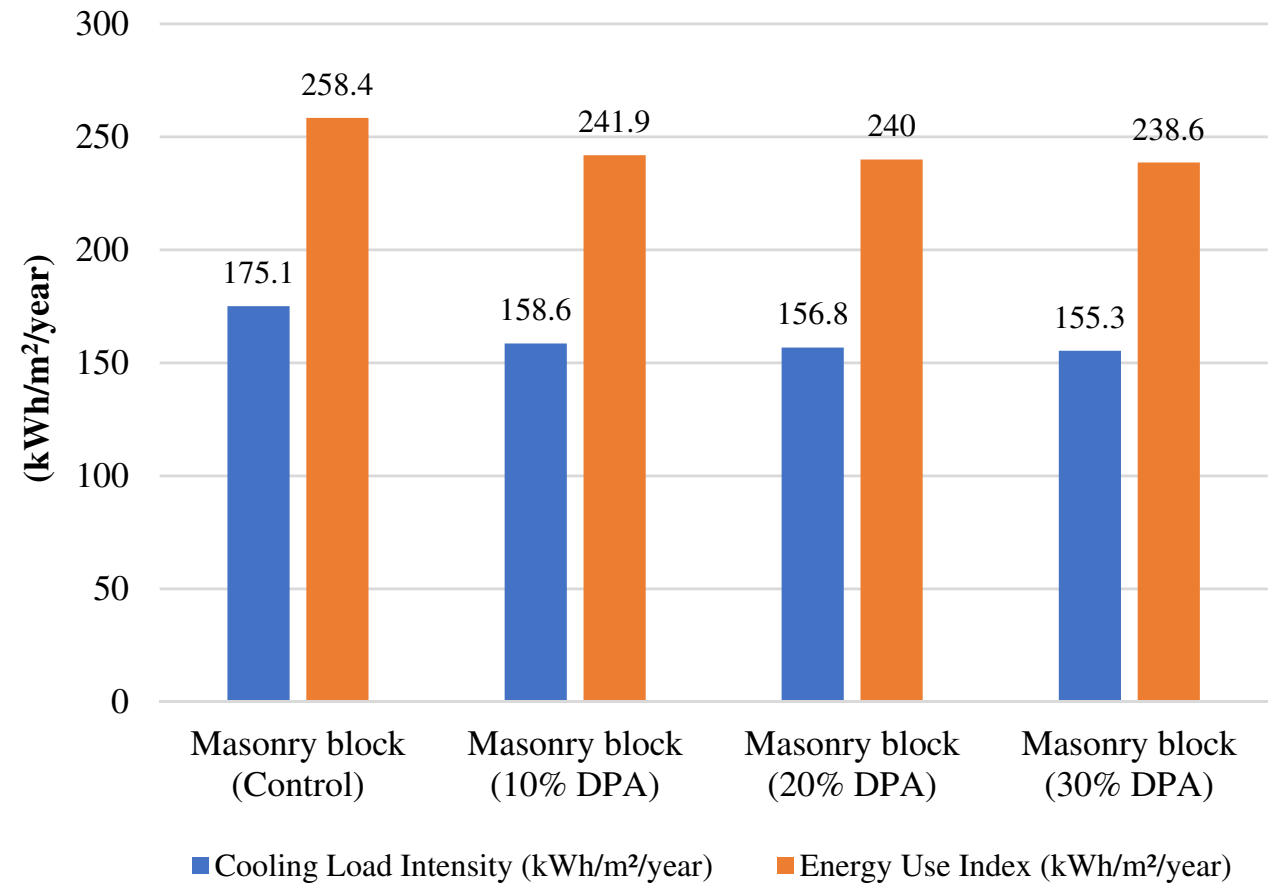

January. This is consistent with the average monthly solar incident radiation of the study location as shown in Fig. 4. The average simulated value of the highest indoor air temperature for the building, with wall 1 (control specimen) was $26{ }^{\circ} \mathrm{C}$, whereas the maximum temperature for the building with wall 4 (30\% DPA) was $24.2^{\circ} \mathrm{C}$. An important issue emerging from this finding is that the average indoor temperature is reduced by $2{ }^{\circ} \mathrm{C}$. This can be attributed to lower U-value of DPA-based block compare to the conventional masonry block which acts as a good thermal insulator. It has been well established that wall insulation plays a crucial role in improving energy consumption and indoor thermal environment [60]. 
Fig. 12 Average monthly indoor temperature variation for various wall options

Fig. 13 Monthly variation in cooling Energy consumption
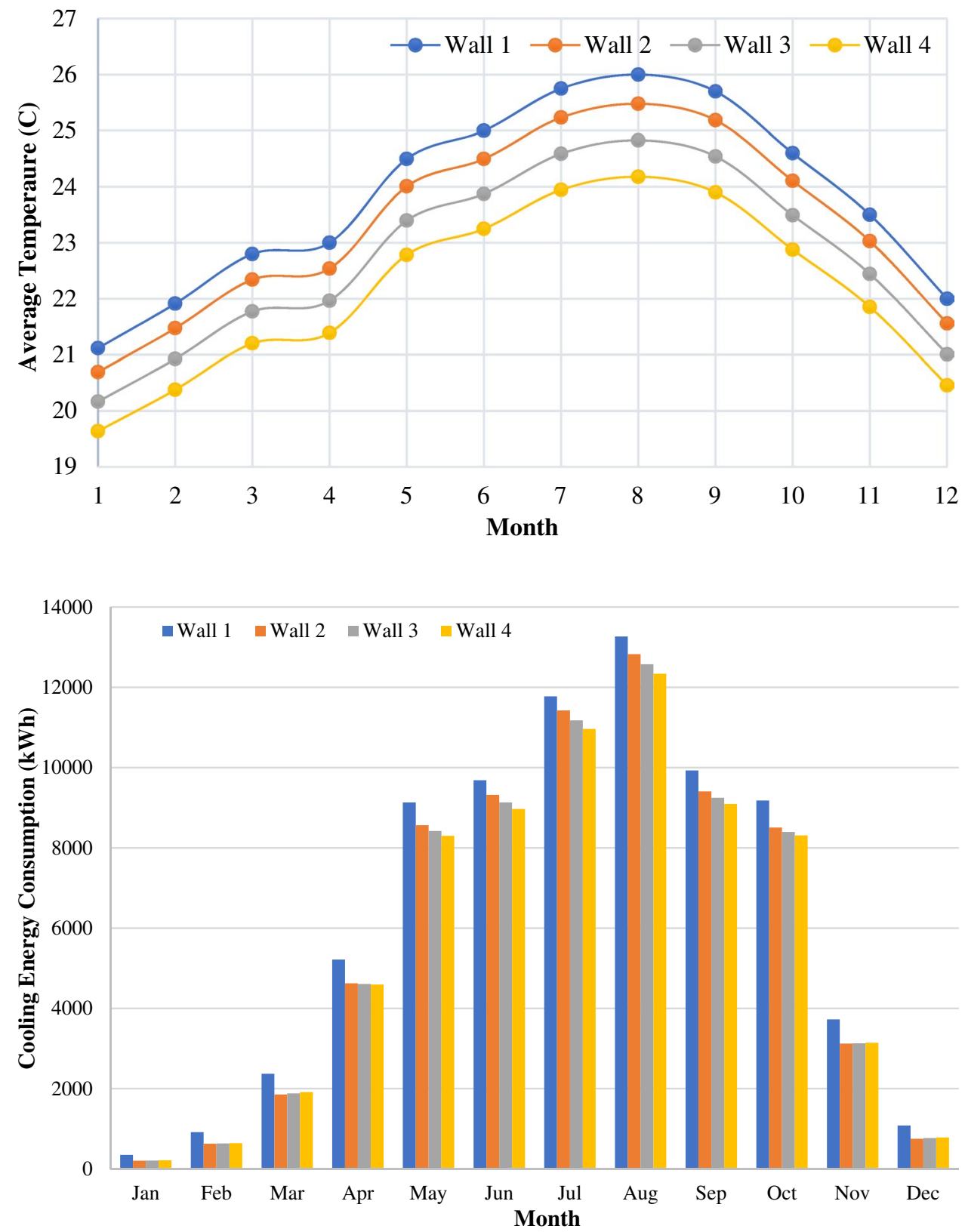

Table 5 Raw material cost

\begin{tabular}{llll}
\hline Material & Cement $^{\mathrm{a}}$ & Sand $^{\mathrm{a}}$ & DPA \\
\hline Cost (USD/50 kg) & 3.67 & 0.32 & - \\
\hline
\end{tabular}

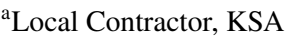

\section{Cost of masonry block}

The unit cost of the novel masonry blocks were evaluated, it depends on the raw material cost. The costs of the raw material, used for comparison purposes are shown in Table 5.
Table 6 Unit cost of masonry block

It can be observed that the important component affecting the cost of the masonry blocks is the cement (Table 5). As compared to the conventional masonry block, DPA-based 


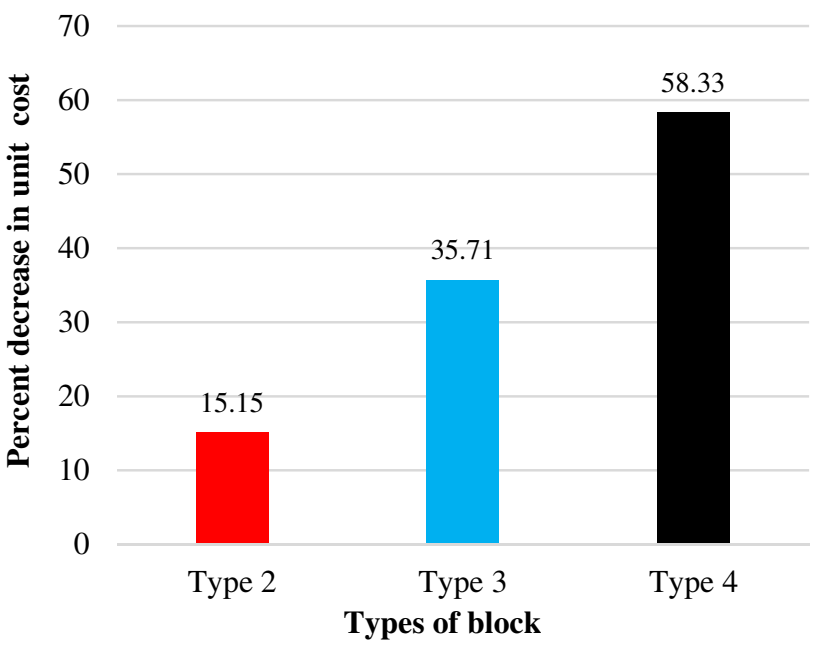

Fig. 14 Percent decrement in unit cost of DPA-based blocks compared to control block (Type 1)

masonry blocks were found to be economical as DPA is the waste material. The unit cost of the bricks for all the options is tabulated in Table 6. It is apparent from Table 6 that the unit cost of the control block (Type 1) is highest, due to the high content of OPC while the unit cost of the DPAbased masonry (Types 2, 3 and 4) blocks decreases with the increase in the proportion of DPA.

The percentage decrease in the unit cost of DPA-based blocks with respect to conventional masonry block (Type 1) was also determined as shown in Fig. 14. The decrement in the unit cost of Type 2 block is observed to be $15.15 \%$, which has been further decreased to $35.71 \%$ (Type 3 ) and $58.33 \%$ (Type 4 ), with the addition of $10 \%$ and $20 \%$ of DPA content respectively. Therefore, it can be posited that the reduction in manufacturing cost of masonry blocks is effected by percentage replacement of OPC by DPA.

\section{Conclusion}

The thermal and energy performance of the novel masonry blocks prepared by the partial replacement of ordinary Portland cement (OPC) with date palm ash (DPA) in the varying dosage of 10, 20 and 30\% were explored. Simulations were carried out employing DesignBuilder software on a typical existing office building located in the Eastern region of Saudi Arabia (Dhahran). The findings of the research are quire convincing, and thus the following conclusions could be deduced:

- The developed masonry blocks fall under the light weight block category in accordance with ASTM C55-11 stand- ard, based on the density of masonry blocks prepared with 10-30\% DPA replacement.

- The increase in thermal resistance ( $R$-value) of the block loaded with $10 \%, 20 \%$, and $30 \%$ DPA in comparison to control block (0\% DPA) were $9.6 \%, 8.1 \%$ and $47.4 \%$ respectively.

- The annual energy consumption and cooling load of the building having type 3 block (30\% DPA), can be reduced by $7.66 \%$ and $11 \%$ respectively, compared to the control block (0\% DPA).

- DPA content in the masonry block (Type 4) is a promising option for reducing heat stress inside the building. It could reduce the average monthly indoor temperature by $2{ }^{\circ} \mathrm{C}$.

- A cost-saving of $11.3 \%$ in the annual energy consumption of the building could be yield with the usage of DPAbased blocks as compared to the conventional masonry blocks.

- The cost analysis shows that DPA-based blocks with $30 \%$ DPA (Type 3) is most effective among the studied blocks as it has the unit cost of $2.76 \$ / \mathrm{m}^{2}$.

Further studies, which take Life cycle assessment (LCA) and Life cycle cost (LCC) of DPA block options are underway which will be published in due course.

\section{Compliance with ethical standards}

Conflict of interest The authors declare that they have no conflict of interest.

Open Access This article is licensed under a Creative Commons Attribution 4.0 International License, which permits use, sharing, adaptation, distribution and reproduction in any medium or format, as long as you give appropriate credit to the original author(s) and the source, provide a link to the Creative Commons licence, and indicate if changes were made. The images or other third party material in this article are included in the article's Creative Commons licence, unless indicated otherwise in a credit line to the material. If material is not included in the article's Creative Commons licence and your intended use is not permitted by statutory regulation or exceeds the permitted use, you will need to obtain permission directly from the copyright holder. To view a copy of this licence, visit http://creativecommons.org/licenses/by/4.0/.

\section{References}

1. Wei, Y., Zhang, X., Shia, Y., Xia, L., Pan, S., Wud, J., Han, M., Zhao, X.: A review of data-driven approaches for prediction and classification of building energy consumption. Renew. Sustain. Energy Rev. 82, 1027-1047 (2018)

2. Mezghani, I., Ben-Haddad, H.: Energy consumption and economic growth: an empirical study of the electricity consumption in Saudi Arabia. Renew. Sustain. Energy Rev. 75, 145-156 (2017)

3. Amasyali, K., El-gohary, N.M.: A review of data-driven building energy consumption prediction studies. Renew. Sustain. Energy Rev. 81, 1192-1205 (2018)

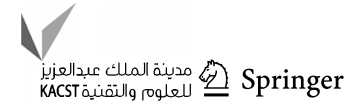


4. Iqbal, I., Al-homoud, M.S.: Parametric analysis of alternative energy conservation measures in an office building in hot and humid climate. Build. Environ. 42, 2166-2177 (2007)

5. Syed, M., Mohamed, S., Abdulrahman, M., Saleh, H.: Analysis of electric energy consumption in an office building in Saudi Arabia. ASHRAE Trans. 106, 173-184 (2000)

6. Building Sector, Saudi for Energy Efficiency Center. https://www. seec.gov.sa/en/energy-sectors/buildings-sector/. Accessed 01 June 2020

7. Khalil, N.M., Algamal, Y.: Environmental and Economical Aspects of Partial Replacement of Ordinary Portland Cement with Saudi Raw Minerals. Silicon 11, 241-255 (2019)

8. Andrew, R.M.: Global $\mathrm{CO} 2$ emissions from cement production. Earth Syst Sci data 195-217, 2018 (2018)

9. Mannan, M.A., Ganapathy, C.: Concrete from an agricultural waste-oil palm shell (OPS). Build. Environ. 39(4), 441-448 (2004)

10. Safiuddin, M., Jumaat, M.Z., Salam, M.A., Islam, M.S., Hashim, R.: Utilization of solid wastes in construction materials. Int. J. Phys. Sci. 5(13), 1952-1963 (2010)

11. Ismail, M., Ismail, M.A., Lau, S.K., Muhammad, B., Majid, Z.: Fabrication of bricks from paper sludge and palm oil fuel ash. Concr. Res. Lett. Asia Pacific Struct. Eng. Conf. APSEC 1(2), 60-66 (2010)

12. Alleman, J.E., Berman, N.A.: Constructive sludge management: biobrick. J. Environ. Eng. 110(2), 301-311 (1984)

13. Chowdhury, S., Mishra, M., Suganya, O.: The incorporation of wood waste ash as a partial cement replacement material for making structural grade concrete: an overview. Ain Shams Eng. J. 6(2), 429-437 (2015)

14. Shannag, M.J.: High strength concrete containing natural pozzolan and silica fume. Cem. Concr. Compos. 22, 399-406 (2000)

15. Nochaiya, T., Wongkeo, W., Chaipanich, A.: Utilization of fly ash with silica fume and properties of Portland cement-fly ashsilica fume concrete. Fuel 89(3), 768-774 (2010)

16. Pode, R.: Potential applications of rice husk ash waste from rice husk biomass power plant. Renew. Sustain. Energy Rev. 53, 14681485 (2016)

17. Al-Kutti, W., Saiful-Islam, A.B.M., Nasir, M.: Potential use of date palm ash in cement-based materials. J. King Saud Univ. Eng. Sci. 31(1), 26-31 (2019)

18. Antoni, M., Rossen, J., Martirena, F., Scrivener, K.: Cement and concrete research cement substitution by a combination of metakaolin and limestone. Cem. Concr. Res. 42(12), 1579-1589 (2012)

19. Langan, B.W., Weng, K., Ward, M.A.: Effect of silica fume and fly ash on heat of hydration of Portland cement. Cem. Concr. Res. 32, 1045-1051 (2002)

20. Li, G., Zhao, X.: Properties of concrete incorporating fly ash and ground granulated blast-furnace slag. Cem. Concr. Compos. 25, 293-299 (2003)

21. Elsayed, A.A.: Influence of silica fume, fly ash, super pozz, and high slag cement on water permeability and strength of concrete. Concr. Res. Lett. 3, 528-540 (2012)

22. Walid-Al-Kutti, N.I.B., Nasir, M., Johari, M.A.M., Saiful-Islam, A.B.M., Manda, A.A.: An overview and experimental study on hybrid binders containing date palm ash, fly ash, OPC and activator composites. Constr. Build. Mater. 159, 567-577 (2018)

23. Al-kutti, W., Islam, A.B.M.S., Nasir, M.: Journal of King Saud University-Engineering Sciences Potential use of date palm ash in cement-based materials. J. King Saud Univ. Eng. Sci. 31(1), 26-31 (2019)

24. Strength, E., Nasir, M.: Performance of date palm ash as a cementitious material by evaluating strength, durability, and characterization. Buildings 9(6), 1-13 (2019)
25. Zeyad, A.M., Husain, A., Tayeh, B.A.: Durability and strength characteristics of high-strength concrete incorporated with volcanic pumice powder and polypropylene fibers. J. Mater. Res. Technol. 9(1), 806-818 (2019)

26. Kannan, D.M., Aboubakr, S.H., El-dieb, A.S., Reda, M.M.: High performance concrete incorporating ceramic waste powder as large partial replacement of Portland cement. Constr. Build. Mater. 144, 35-41 (2017)

27. Singh, M., Srivastava, A., Bhunia, D.: An investigation on effect of partial replacement of cement by waste marble slurry. Constr. Build. Mater. 134, 471-488 (2017)

28. Kupwade-patil, K., et al.: Impact of embodied energy on materials/buildings with partial replacement of ordinary Portland Cement (OPC) by natural pozzolanic volcanic ash. J. Clean. Prod. 177, 547-554 (2018)

29. Blaisi, N.I.: Environmental assessment of utilizing date palm ash as partial replacement of cement in mortar. J. Hazard. Mater. 357, 175-179 (2018)

30. Benmansour, N., Agoudjil, B., Gherabli, A., Kareche, A.: Thermal and mechanical performance of natural mortar reinforced with date palm fibers for use as insulating materials in building. Energy Build. 81, 98-104 (2014)

31. Xu, Q., Zang, H.: Comments on ' Generation of typical meteorological year for different climates of China ' [Energy, 35 (2010) 1946 e 1953 ]. Energy 36(10), 6285-6288 (2011)

32. Weingrill, H., Hohenauer, W., Resch-fauster, K., Zauner, C.: Analyzing thermal conductivity of polyethylene-based compounds filled with copper. Macromol. Mater. Eng. 1800644, 1-14 (2019)

33. Linseis: User's Manual of Transient Hot Bridge Analyzer THB100 (2013)

34. Galán-Arboledas, R.J., Cotes-Palomino, M.T., Bueno, S., Martínez-García, C.: Evaluation of spent diatomite incorporation in clay based materials for lightweight bricks processing. Constr. Build. Mater. 144, 327-337 (2017)

35. Abdul-Mujeebu, M., Ashraf, N.: Impact of location and deadband on energy performance of nano aerogel glazing for office building in Saudi Arabia. Build. Res. Inf. 48(6), 645-658 (2020)

36. ASHRAE, ANSI/ASHRAE Standard 62.1-2013. Ventilation for acceptable indoor air quality. American Society of Heating, Refrigerating, and Air-Conditioning Engineers, Inc., Atlanta, GA (2013)

37. Alaidroos, A., Krarti, M.: Optimal design of residential building envelope systems in the Kingdom of Saudi Arabia. Energy Build. 86, 104-117 (2015)

38. Mohammed, M.A.-A.A.-Q., Alhefnawi, A.M.: Thermal insulation efficiency of unventilated air-gapped facades in hot climate. Arab. J. Sci. Eng. 42, 1155-1160 (2017)

39. Khalid, W., Abdul, M., Mohammed, A., Algarny, M.: Impact of external shading strategy on energy performance of multi- story hotel building in hot-humid climate. Energy 169, 1166-1174 (2019)

40. Al-hadhrami, L.M., Ahmad, A.: Assessment of thermal performance of different types of masonry bricks used in Saudi Arabia. Appl. Therm. Eng. 29(5-6), 1123-1130 (2009)

41. Corinaldesi, V., Mazzoli, A., Moriconi, G.: Mechanical behaviour and thermal conductivity of mortars containing waste rubber particles. Mater. Des. 32(3), 1646-1650 (2011)

42. da Milani, A.P., Labaki, L.C.: Physical, mechanical, and thermal performance of cement-stabilized rammed earth-rice husk ash walls. J. Mater. Civ. Eng. 24(6), 775-782 (2011)

43. Hai-Alami, A.: Experiments on unfired masonry clay bricks mixed with palm fronds and date pits for thermal insulation applications. J. Renew. Sustain. Energy 5, 023136 (2013)

44. Rahman, M.E., Boon, A.L., Muntohar, A.S., Hashem-Tanim, M.N., Pakrashi, V.: Performance of masonry blocks incorporating palm oil fuel ash. J. Clean. Prod. 78(2014), 195-201 (2014) 
45. Carrasco-Hurtado, B., Corpas-Iglesias, F.A., Cruz-Pérez, N., Terrados-Cepeda, J., Pérez-Villarejo, L.: Addition of bottom ash from biomass in calcium silicate masonry units for use as construction material with thermal insulating properties. Constr. Build. Mater. 52(2014), 155-165 (2014)

46. Benmansour, N., Agoudjil, B., Gherabli, A., Kareche, A., Boudenne, A.: Thermal and mechanical performance of natural mortar reinforced with date palm fibers for use as insulating materials in building. Energy Build. 81, 98-104 (2014)

47. Wu, J., Bai, G., Zhao, H., Li, X.: Mechanical and thermal tests of an innovative environment-friendly hollow block as self-insulation wall materials. Constr. Build. Mater. 93, 342-349 (2015)

48. Danso, H., Martinson, D.B., Ali, M., Williams, J.B.: Physical, mechanical and durability properties of soil building blocks reinforced with natural fibres. Constr. Build. Mater. 101, 797-809 (2015)

49. Li, J., Cao, W., Chen, G.: The heat transfer coefficient of new construction—brick masonry with fly ash blocks. Energy 86, 240-246 (2015)

50. Raut, A.N., Gomez, C.P.: Thermal and mechanical performance of oil palm fiber reinforced mortar utilizing palm oil fly ash as a complementary binder. Constr. Build. Mater. 126, 476-483 (2016)

51. Manohar, K.: Experimental Investigation of Building Thermal Insulation from Agricultural By-products. Br. J. Appl. Sci. Technol. 2(3), 227-239 (2012)

52. Bentz, C.J., Peltz, M.A., Duran-Herrera, A., Valdez, P.: Thermal properties of high-volume fly ash mortars and concretes. J. Build. Phys. 34(3), 263-275 (2011)
53. Ahmadf, F., Alam, I.: Physical, mechanical and durability characteristics of date palm frond stalks as reinforcement in structural concrete. Int. J. Cem. Compos. Light. Concr. 10, 175-181 (1988)

54. Al-fakih, A., Mohammed, B.S., Liew, M.S., Nikbakht, E.: Incorporation of waste materials in the manufacture of masonry bricks: an update review. J. Build. Eng. 21, 37-54 (2019)

55. Kim, J.-J., Moon, J. W.: Impact of insulation on building energy consumption. In: Building simulation, pp. 674-680 (2009)

56. Abdul, M., Mohammad, I.: Energy performance of windows in office buildings considering daylight integration and visual comfort in hot climates. Energy Build. 108, 307-316 (2015)

57. Abdul-Mujeebu, M., Ashraf, N., Alsuwayigh, A.: Energy performance and economic viability of nano aerogel glazing and nano vacuum insulation panel in multi-story office building. Energy 113, 949-956 (2016)

58. Abdul-Mujeebu, M., Ashraf, N., Alsuwayigh, A.H.: Effect of nano vacuum insulation panel and nanogel glazing on the energy performance of office building. Appl. Energy 173, 141-151 (2016)

59. Al-Ugla, A.A., El-Shaarawi, M.A.I., Said, S.A.M., Al-Qutub, A.M.: Techno-economic analysis of solar-assisted air-conditioning systems for commercial buildings in Saudi Arabia. Renew. Sustain. Energy Rev. 54, 1301-1310 (2016)

60. Fang, Z., Li, N., Li, B., Luo, G., Huang, Y.: The effect of building envelope insulation on cooling energy consumption in summer. Energy Build. 77, 197-205 (2014) 